\title{
Half-Life Time and Control Frequency of Vitamin K- Dependent Coagulation Factors
}

Citation for published version (APA):

van Dam-Mieras, M. C. E., \& Hemker, H. C. (1983). Half-Life Time and Control Frequency of Vitamin KDependent Coagulation Factors: Theoretical Considerations on the Place of Factor VII in the Control of Oral Anticoagulation Therapy. Haemostasis, 13(3), 201-208. https://doi.org/10.1159/000214728

Document status and date:

Published: 01/01/1983

DOI:

10.1159/000214728

Document Version:

Other version

\section{Please check the document version of this publication:}

- A submitted manuscript is the version of the article upon submission and before peer-review. There can be important differences between the submitted version and the official published version of record.

People interested in the research are advised to contact the author for the final version of the publication, or visit the DOI to the publisher's website.

- The final author version and the galley proof are versions of the publication after peer review.

- The final published version features the final layout of the paper including the volume, issue and page numbers.

Link to publication

\footnotetext{
General rights rights.

- You may freely distribute the URL identifying the publication in the public portal. please follow below link for the End User Agreement:

www.umlib.nl/taverne-license

Take down policy

If you believe that this document breaches copyright please contact us at:

repository@maastrichtuniversity.nl

providing details and we will investigate your claim.
}

Copyright and moral rights for the publications made accessible in the public portal are retained by the authors and/or other copyright owners and it is a condition of accessing publications that users recognise and abide by the legal requirements associated with these

- Users may download and print one copy of any publication from the public portal for the purpose of private study or research.

- You may not further distribute the material or use it for any profit-making activity or commercial gain

If the publication is distributed under the terms of Article $25 \mathrm{fa}$ of the Dutch Copyright Act, indicated by the "Taverne" license above, 


\title{
Half-Life Time and Control Frequency of Vitamin K-Dependent Coagulation Factors
}

\section{Theoretical Considerations on the Place of Factor VII in the Control of Oral Anticoagulation Therapy}

\author{
M.C.E. van Dam-Mieras, H.C. Hemker
}

Department of Biochemistry, Limburg University, Maastricht, The Netherlands

Key Words. Half-life times of coagulation factors · Factor VII · Control frequency of anticoagulation. Theoretical model

\begin{abstract}
A short review about the place of coagulation factor VII in the initial phase of blood coagulation is given. A theoretical model describing the relationship between the halflife times of vitamin K-dependent coagulation factors and the control frequency of oral anticoagulation therapy is presented. The constraints that control frequency imposes on the type of determination to be carried out are discussed.
\end{abstract}

\section{Introduction}

It is well known from the literature that part of the coagulation cascade reactions proceed at lipid/water interfaces. The enzymes and substrates in these surface-mediated reactions are the vitamin $\mathrm{K}$-dependent coagulation factors. It is possible to regulate the efficiency of the heterogeneous catalysis through manipulation of the affinity for lip$\mathrm{id} /$ water interfaces of the coagulation factors involved. Oral anticoagulation is based on this principle. Today, oral anticoagulation therapy is usually controlled by a general analytical method sensitive to the overall effect on several of the vitamin K-dependent coagulation factors (VII, IX, X and II). The advent of automatable amidolytic tests measuring the different vitamin K-dependent factors independently actualizes the discussion on the relative importance of single vitamin K-dependent factors in the control of oral anticoagulation therapy. This discussion in the older literature mostly goes in the form of debates on the importance of 'factor $\mathrm{X}$ sensitivity' of thromboplastins. The hard facts on which one can decide what factors are important in this respect are: (1) The biological half-life times of the vitamin K-dependent coagulation factors. (2) The levels of the vitamin $\mathrm{K}$-dependent coagulation factors that are acceptable to ensure adequate anticoagulation (upper limit) and to prevent bleeding (lower limit). 
Whereas point 1 is well known [van der Meer et al., 1968], no hard data are available on point 2; it is not known, for example, whether $2.5 \%$ of factor VII will cause a serious bleeding tendency or not. In other words it is not easily predicted how a factor VII level as low as $2.5 \%$ will be expressed in the overall coagulation capacity of blood, or whether a level of $30 \%$ of factor IX will carry a significant risk of thrombosis.

Although the discussion on what level of which individual factor is acceptable has not been carried to a conclusion, in practice the decision for all practical purposes has already been made on the moment that the frequency of the control of oral anticoagulant therapy has been decided, because there is a relationship between the control frequency and the half-life time of the coagulation factors actually followed in an overall test. Qualitatively this will be easily understood. It is no use to control factor II levels daily if the response of the factor II level to changes in dosage of oral anticoagulants is limited by the fact that its biological half-life time is $2 \frac{1 / 2}{2}$ days. On the other hand it does not seem useful either to choose a parameter with a biological half-life of a few hours when the control frequency is only one control per 6 weeks. The situation is akin to the registration of electric phenomena on a strip-chart recorder. If the dampening of the instrument is too high, fast signals will be missed, if it is too low, too much noise will be recorded. We present in this article a theoretical model meant to explore the relation between the half-life times of the factors to be measured and the control frequency. We also discuss the constraints that control frequency imposes on the type of determination to be carried out.

\section{Special Position of Factor VII among the Vitamin K-Dependent Coagulation \\ Factors}

Recent research in the coagulation field has shown that the familiar picture of an intrinsic and extrinsic pathway of coagulation joining at the factor $\mathrm{X}$ activation step is far too simple. There exist close connections between the initiating reactions of both pathways [see also the contribution of Prydz in this issue].

In the 'classical' concept factor VII is activated upon interaction with tissue thromboplastin and the intrinsic pathway is triggered by the exposure of blood to negatively charged surfaces. Several authors have shown that factor $\mathrm{XII}_{\mathrm{a}}$ and Hageman factor fragments activate bovine factor VII [Altman and Hemker, 1967; Kisiel et al., 1977; Radcliffe et al., 1977]. Seligsohn et al. [1978, $1979 \mathrm{a}, \mathrm{b}$ ] showed in a human system that both XII $_{\mathrm{a}}$ and IX $_{\mathrm{a}}$ activate factor VII. These authors state that after surface contact, $\mathrm{XII}_{\mathrm{a}}$ is the principal activator of factor VII and after clotting, IX $_{\mathrm{a}}$ is the principal factor VII activator. Kallikrein acts indirectly by activating factors XII and XI. Morrison-Silverberg and Jesty [1981] using a bovine system argued that a ternary complex of tissue factor, factor VII and factor $\mathrm{X}_{\mathrm{a}}$ would be the form of factor VII responsible for a further generation of factor $\mathrm{IX}_{\mathrm{a}}$ and factor $\mathrm{X}_{\mathrm{a}}$ during the period preceding clot formation. Only $0.2 \%$ of the total plasmatic content of factor $\mathrm{X}$ needs to be activated to give a maximal expression of VII activity and the generation of activity in the system could be extremely rapid because it would only depend upon the formation of a Michaelis-type complex and not upon a proteolytic splitting. Radcliffe and Nemerson [1975, 1976] have shown that in a 
purified system first there is a rapid activation followed by a slower inactivation of factor VII by factor $\mathrm{X}_{\mathrm{a}}$. In whole plasma, where inhibitors of factor $\mathrm{X}_{\mathrm{a}}$ are also present, an inactivation of factor $\mathrm{VII}_{\mathrm{a}}$ by factor $\mathrm{X}_{\mathrm{a}}$ is not so easily proven, but it is not unlikely that also here factor $X_{a}$ might exert a negative control function. Furthermore, thrombin and plasmin can also enhance factor VII activity [Zur and Nemerson, 1980; Østerud et al., 1980].

On the other hand, both in human and bovine systems factors IX and X can be activated by the tissue factor-VII $\mathrm{a}_{\mathrm{a}}$ complex [Josso and Prou-Wartelle, 1965; Østerud and Rapaport, 1977, 1980; Jesty and Silverberg, 1979]. It has been shown that factors IX and $\mathrm{X}$ are competitive inhibitors with regard to their respective activation by the tissue factor-VII ${ }_{\mathrm{a}}$ complex. When the activation of factors IX and $\mathrm{X}$ was studied in a system mimicking bovine plasmatic conditions [Jesty and Silverberg, 1979] X activation proceeded about 7 times faster than IX activation. Using human reagents, Østerud and $R a$ paport [1980] reported that the two activation rates were equal.

Finally there are clinical indications pointing to the close connection between intrinsic and extrinsic pathways. Usually, patients with very low levels of factor XII or factor XI do not show a bleeding tendency while the hemorrhagic problems in factor VIII- and factor IX-deficient patients are well known. Aiyappa [1981a, b] described a chromogenic analogue of the APTT test that turned out to be sensitive not only to deficiency of the factors XII, prekallikrein, XI, IX, VIII, V, X and II but to factor VII deficiency as well. Bertina et al. [1981] described a patient with an abnormal factor X molecule; it is normally activated by the factors
IX $_{\mathrm{a}}, \mathrm{IX}_{\mathrm{a}}+\mathrm{VIII}$ and RVV-X but only very slowly by the thromboplastin factor VII complex. This patient never showed bleeding complications.

The short review given above [see also the article of Prydz in this issue] clearly shows that the extrinsic and intrinsic pathways of the coagulation cascade are intimately linked. Many experiments will be needed to completely elucidate this complicated system. However, one thing emerges very clearly: factor VII must play a central and important role in the initial phase of blood coagulation. This idea is further supported by the fact that contrary to the other vitamin K-dependent coagulation factor zymogens, factor VII has relatively strong esterase activity in its native (one-chain) form [Zaugg, 1980; Zur and Nemerson, 1980; Radcliffe and Nemerson, 1975]. Finally the in vitro occurrence of coldpromoted activation, the fact that factor $\mathrm{VII}_{\mathrm{a}}$ in plasma stored at $4{ }^{\circ} \mathrm{C}$ is stable for several days [Seligsohn et al., 1978a, b], the persistence of activated factor VII in circulation for several hours $\left(t^{1 / 2}=144 \mathrm{~min}\right)$ after transfusion of factor IX concentrates [Seligsohn et al., 1979a, b] and the observation that antithrombin III does not inactivate factor $\mathrm{VII}_{\mathrm{a}}$ [Østerud et al., 1976; Jesty, 1978] all point to the special place factor VII takes among the serine esterase enzymes of the coagulation cascade.

Factor VII might be an important factor in the control of bleeding and thrombotic tendencies. Clinical assays of factor VII and its activity state in plasma could be of great diagnostic importance [Hemker et al., 1976; Poller et al., 1981; Avvisati et al., 1980; Seligsohn et al., 1978b; Aiyappa, 1981a, b]. On the basis of these observations the importance of measuring factor VII theoretically may be sustained. On the other hand, having in mind 
the relatively short half-time value of factor VII [van der Meer et al., 1968] one may ask if a factor VII assay is suitable for the control of oral anticoagulation therapy when the control frequency in practice varies between once per day and once per 6 weeks.

\section{Theoretical Model}

In the following a theoretical model is presented which gives a relation between the biological half-life times of vitamin K-dependent coagulation factors and the control frequency of anticoagulation therapy. In the construction of the model it is assumed that the coagulation factor levels approach the level eventually dictated by the rate of synthesis in the liver by first-order kinetics and that the processes leading to increase respectively decrease of these levels are characterized by the same kinetic parameters [van der Meer et al., 1968]. Figure 1 shows a practical situation. At a given time $t=0$, the level of a given vitamin $\mathrm{K}$-dependent coagulation factor is $\alpha$ and $t$ units of time, later the level of the same factor is $\beta$. It is not likely that during the time lapse $t$ the coagulation factor level follows the straight line $\alpha-\beta$; it will sometimes lie above and sometimes beneath this line. The lowest value that can be reached between two controls $\alpha$ and $\beta$ is found when the level decreases after point $\alpha$ and then again increases to reach level $\beta$. This situation is represented by the line $\alpha-n_{\min }-\beta$ in figure 2.

The curves $\alpha-n_{\min }$ and $n_{\min }-\beta$ can be described by first-order kinetics (see above):

$$
\begin{aligned}
& \mathrm{n}_{\min }=\alpha \mathrm{e}^{-\mathrm{kt} t_{\min }} \\
& \text { and } 100-\beta=\left(100-\mathrm{n}_{\min }\right) \mathrm{e}^{-\mathrm{k}\left(\mathrm{t}-\mathrm{t}_{\min }\right)}
\end{aligned}
$$

Substitution of equation 1 in equation 2 gives:

$$
\frac{100-\beta}{100-\mathrm{n}_{\min }} \cdot \frac{\mathrm{n}_{\min }}{\alpha}=\mathrm{e}^{-\mathrm{kt}}
$$

which, because of the first-order character, can be rewritten as:

$$
\frac{100-\beta}{100-\mathrm{n}_{\min }} \cdot \frac{\mathrm{n}_{\min }}{\alpha}=(1 / 2)^{t / t / 2}
$$

For reasons of simplicity of the calculations to follow a new variable $\mathrm{q}$ is introduced:

$$
1 / \mathrm{q}=(1 / 2)^{t / t / 2},
$$

rearrangement of equation 3 then gives:

$$
\mathrm{n}_{\min }=\frac{100}{\mathrm{q}\left(\frac{100-\beta}{\alpha}\right)+1}
$$

Equation 4 is used to calculate table I starting from the situation of stable anticoagulation $(\alpha=\beta)$.

From table I it follows that when a vitamin K-dependent coagulation factor level of $20 \%$ is maintained in 'stable anticoagulation', dangerously low values $(<5 \%)$ can be reached within 3 half-time values if sudden overdosage causes blocking of the coagulation factor synthesis.

Exactly the same reasoning can be followed to find the value $n_{\max }$ between the points $\alpha$ and $\beta$ (cf. fig. 2); for the curve $\alpha-n_{\max }$ we can write:

$$
100-\mathrm{n}_{\max }=(100-\alpha) \mathrm{e}^{-\mathrm{kt} t_{\max }}
$$

and for the descending limb of the curve

$$
\beta=n_{\max } e^{-k\left(t-t_{\max }\right)}
$$

Combination of equations 5 and 6 gives

$$
\frac{100-\mathrm{n}_{\max }}{\alpha} \cdot \frac{\beta}{\mathrm{n}_{\max }}=\mathrm{e}^{-\mathrm{kt}}
$$


Fig. 1. Time course of the coagulation factor level between two successive controls. At the time $\mathrm{t}=0$ a level $\alpha$ is measured; $t$ units of time later the level is $\beta$.

Fig. 2. Representation of the theoretically calculated maximal $\left(\mathrm{n}_{\max }\right)$ and minimal $\left(\mathrm{n}_{\min }\right)$ values the coagulation factor level can reach between two successive controls ( $\alpha$ and $\beta$ ).
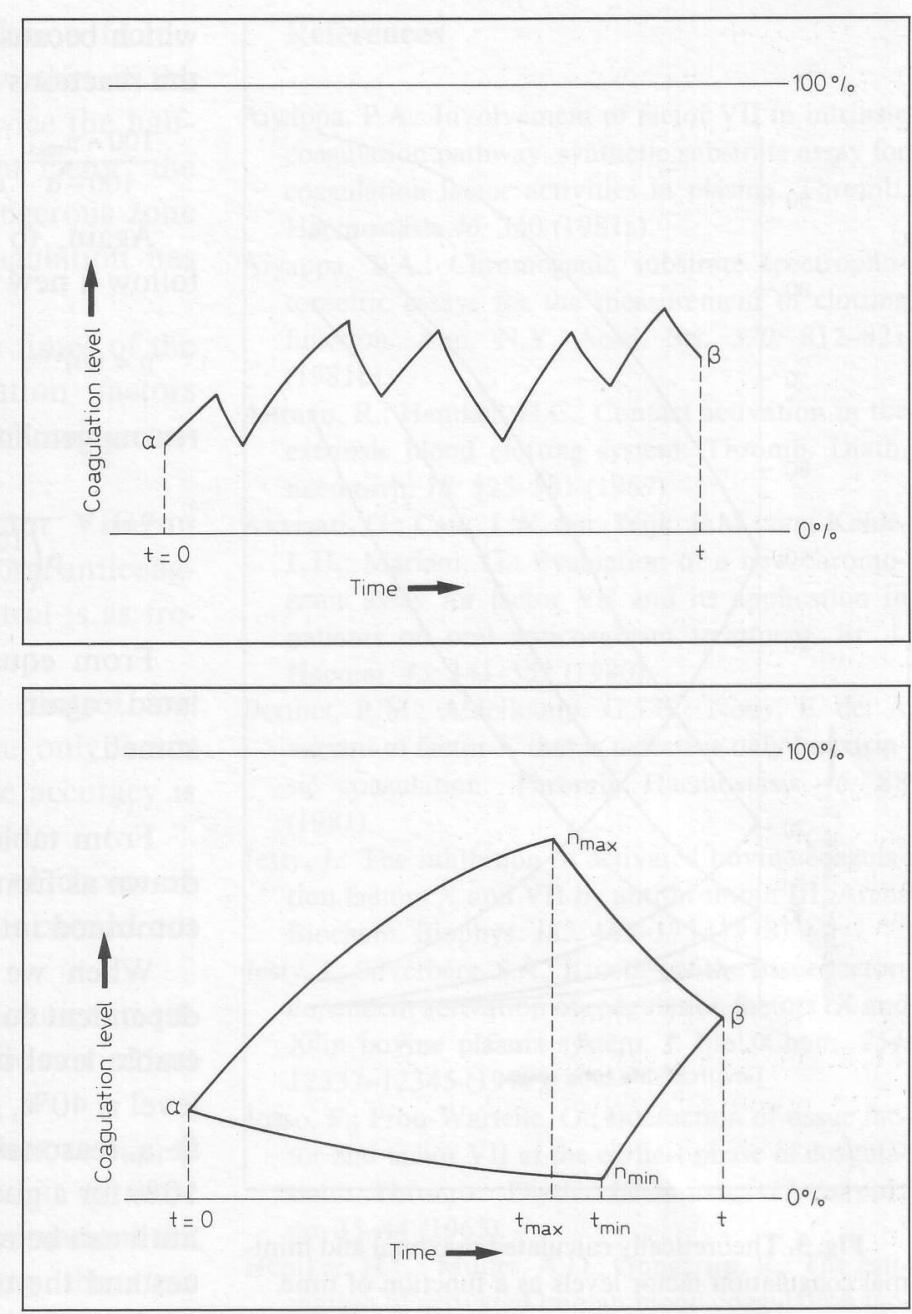

Table I. $\mathrm{n}_{\min }$ values as a function of $\alpha, \beta$ and $\left(\mathrm{t} / \mathrm{t}_{1 / 2}\right)$

\begin{tabular}{|c|c|c|c|c|c|c|c|c|}
\hline $\begin{array}{l}\mathrm{t} / \mathrm{t}_{1 / 2}: \\
\mathrm{q}:\end{array}$ & $\begin{array}{l}1 / 4 \\
1.19\end{array}$ & $\begin{array}{l}1 / 3 \\
1.26\end{array}$ & $\begin{array}{l}1 / 2 \\
1.41\end{array}$ & $\begin{array}{l}1 \\
2\end{array}$ & $\begin{array}{l}2 \\
4\end{array}$ & $\begin{array}{l}3 \\
8\end{array}$ & $\begin{array}{l}4 \\
16\end{array}$ & $\begin{array}{l}5 \\
32\end{array}$ \\
\hline$\alpha=\beta=5$ & 4.2 & 4.0 & 3.6 & 2.6 & 1.3 & 0.6 & 0.3 & 0.2 \\
\hline$\alpha=\beta=10$ & 8.5 & 8.1 & 7.3 & 5.3 & 2.7 & 1.4 & 0.7 & 0.3 \\
\hline$\alpha=\beta=15$ & 12.9 & 12.3 & 11.1 & 8.1 & 4.2 & 2.2 & 1.1 & 0.5 \\
\hline$\alpha=\beta=20$ & 17.4 & 16.5 & 15.1 & 11.1 & 5.9 & 3.0 & 1.5 & 0.8 \\
\hline$\alpha=\beta=25$ & 21.9 & 20.9 & 19.1 & 14.3 & 7.7 & 4.0 & 2.0 & 1.0 \\
\hline$\alpha=\beta=50$ & 45.7 & 44.2 & 41.5 & 33.3 & 20.0 & 11.1 & 5.9 & 3.0 \\
\hline
\end{tabular}




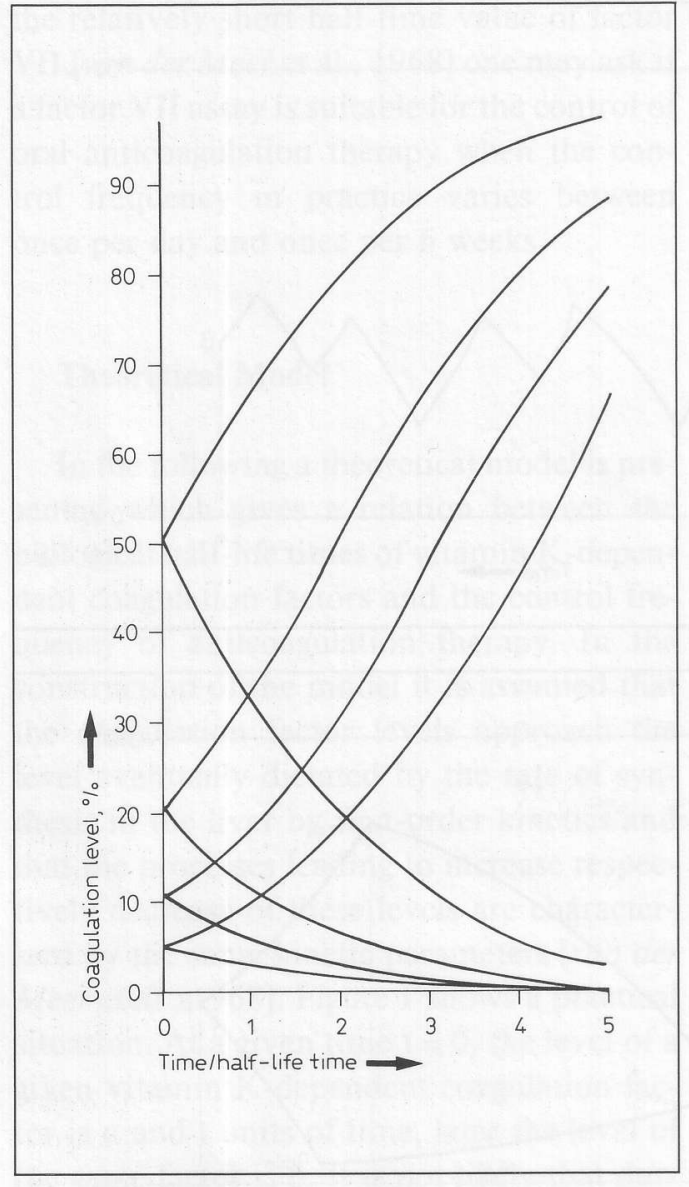

Fig. 3. Theoretically calculated maximal and minimal coagulation factor levels as a function of time. which because of the first-order character of the reactions can be written as:

$$
\frac{100-\mathrm{n}_{\max }}{100-\alpha} \cdot \frac{\beta}{\mathrm{n}_{\max }}=(1 / 2)^{t / t / 1 / 2}
$$

Again, to simplify the calculations that follow a new variable $\mathrm{p}$ is introduced:

$$
\mathrm{p}=(1 / 2)^{t / 1 / 2,}
$$

rearrangement of equation 7 then gives

$$
\mathrm{n}_{\max }=\frac{100}{\mathrm{p}\left(\frac{100-\alpha}{\beta}\right)+1}
$$

From equation 8 table II can be calculated, again 'stable' anticoagulation is assumed.

From table II similar conclusions can be drawn as from table I. Tables I and II can be combined into figure 3 .

When we assume that for vitamin $\mathrm{K}$ dependent coagulation factors the lowest tolerable level is $4 \%$ and the highest tolerable level is $40 \%$, it can be seen from figure 3 that at a reasonable coagulation factor level of $10 \%$ for a given coagulation factor the lower limit can be reached within 1.5 half-time val-

\begin{tabular}{|c|c|c|c|c|c|c|c|c|}
\hline $\begin{array}{l}t / t_{1 / 2}: \\
p:\end{array}$ & $\begin{array}{l}1 / 4 \\
0.84\end{array}$ & $\begin{array}{l}1 / 3 \\
0.79\end{array}$ & $\begin{array}{l}1 / 2 \\
0.71\end{array}$ & $\begin{array}{l}1 \\
0.50\end{array}$ & $\begin{array}{l}2 \\
0.25\end{array}$ & $\begin{array}{l}3 \\
0.12\end{array}$ & $\begin{array}{l}4 \\
0.06\end{array}$ & $\begin{array}{l}5 \\
0.03\end{array}$ \\
\hline$\alpha=\beta=5$ & 5.9 & 6.2 & 6.9 & 9.5 & 17.4 & 30.4 & 46.7 & 63.7 \\
\hline$\alpha=\beta=10$ & 11.7 & 12.3 & 13.5 & 18.2 & 30.8 & 48.1 & 64.9 & 78.7 \\
\hline$\alpha=\beta=15$ & 17.4 & 18.3 & 19.9 & 26.1 & 41.4 & 59.5 & 74.6 & 85.5 \\
\hline$\alpha=\beta=20$ & 22.9 & 24.0 & 26.0 & 33.3 & 50.0 & 67.6 & 80.6 & 89.3 \\
\hline$\alpha=\beta=25$ & 28.4 & 29.7 & 31.9 & 40.0 & 57.1 & 73.5 & 84.7 & 91.7 \\
\hline$\alpha=\beta=50$ & 54.3 & 55.9 & 58.5 & 66.7 & 80.0 & 89.3 & 94.3 & 97.1 \\
\hline
\end{tabular}
ues and the upper limit within 2.6 half-time

Table II. $n_{\max }$ values as a function of $\alpha, \beta$ and $\left(t / t_{1 / 2}\right)$ 
values of the respective coagulation factor. These calculations clearly show that if the control interval is more than twice the halflife time of a given coagulation factor, the patient may have been in a dangerous zone even if perfectly stable anticoagulation has been observed $(\alpha=\beta)$.

Having in mind the half-life times of the vitamin $\mathrm{K}$-dependent coagulation factors [van der Meer et al., 1968] the following conclusions are justified:

(1) The time course of factor VII can never be used for the control of oral anticoagulation therapy even if the control is as frequent as once per $24 \mathrm{~h}$.

(2) In all cases where the control frequency is once weekly or less, the only factor that can be followed with some accuracy is factor II.

(3) Factor IX is the factor of choice in crucial situations when control is carried out daily.

(4) Factor $X$ is the factor of choice in situations when the control has to be carried out 2-3 times weekly.

Of course the theoretical lines $\alpha-n_{\min }-\beta$ and $\alpha-n_{\max }-\beta$ in figure 2 represent extreme situations and in most practical situations the coagulation factor levels during the time lapse $t$ will lie within the theoretical envelope $\alpha-n_{\min }-\beta-n_{\max }$ scattered around the line $\alpha-\beta$. At the moment statistical experiments are carried out to test the theoretical model introduced above. These statistical experiments will provide knowledge about the scattering of the coagulation factor levels around the line $\alpha-\beta$ during the time lapse t. In other words, the statistical experiments will give us a realistic picture of the fluctuations in coagulation factor level during the periods between successive controls of anticoagulation therapy.

\section{References}

Aiyappa, P.A.: Involvement of factor VII in intrinsic coagulation pathway: synthetic substrate assay for coagulation factor activities in plasma. Thromb. Haemostasis 46: 350 (1981a).

Aiyappa, P.A.: Chromogenic substrate spectrophotometric assays for the measurement of clotting function. Ann. N.Y. Acad. Sci. 370: 812-821 (1981b).

Altman, R.; Hemker, H.C.: Contact activation in the extrinsic blood clotting system. Thromb. Diath. haemorrh. 18: 525-531 (1967).

Avvisati, G.; Cate, J.W. ten; Wijk, E.M. van; Kahlé, L.H.; Mariani, G.: Evaluation of a new chromogenic assay for factor VII and its application in patients on oral anticoagulant treatment. Br. J. Haemat. 45: 343-352 (1980).

Bertina, R.M.; Alderkamp, G.J.H.; Nooy, E. de: A variant of factor $\mathrm{X}$ that is defective only in extrinsic coagulation. Thromb. Haemostasis 46: 88 (1981).

Jesty, J.: The inhibition of activated bovine coagulation factors X and VII by antithrombin III. Archs Biochem. Biophys. 185: 165-173 (1978).

Jesty, J.; Silverberg, S.A.: Kinetics of the tissue factordependent activation of coagulation factors IX and $\mathrm{X}$ in bovine plasma system. J. biol. Chem. 254: 12337-12345 (1979).

Josso, F.; Prou-Wartelle, O.: Interaction of tissue factor and factor VII at the earliest phase of coagulation. Thromb. Diath. haemorrh. 17: suppl., pp. 35-44 (1965).

Hemker, H.C.; Muller, A.D.; Gonggrijp, R.: The estimation of activated human blood coagulation factor VII. J. mol. Med. 1: 127-134 (1976).

Kisiel, W.; Fujikawa, K.; Davie, E.W.: Activation of bovine factor VII (proconvertin) by factor $\mathrm{XII}_{\mathrm{a}}$ (activated Hageman factor). Biochemistry 16: 4189-4149 (1977).

Meer, J. van der; Hemker, H.C.; Loeliger, E.A.: Pharmacological aspects of vitamin $\mathrm{K}_{1}$. A clinical and experimental study in man. Thromb. Diath. haemorrh. 19: 1-95 (1968).

Morrison-Silverberg, S.A.; Jesty, J.: The role of activated factor $\mathrm{X}$ in the control of bovine coagulation factor VII. J. biol. Chem. 256: 1625-1630 (1981).

Østerud, B.; Miller-Andersson, M.; Abildgaard, U.; Prydz, H.: The effect of anti-thrombin III on the 
activity of coagulation factors VII, IX and X. Thromb. Haemostasis 35: 295-304 (1976).

Østerud, B.; Rappaport, S.I.: Activation of factor IX by the reaction product of tissue factor and factor VII: additional pathway for initiating blood coagulation. Proc. natn. Acad. Sci. USA 74: 5260-5264 (1977).

Østerud, B.; Rappaport, S.I.: Activation of ${ }^{125}$ I-factor IX and ${ }^{125}$ I-factor X: effect of tissue factor and factor VII, factor $X_{\mathrm{a}}$ and thrombin. Scand. J. Haematol. 24: 213-226 (1980).

Poller, L.; Thomson, J.M.; Bodzenta, A.; Easton, A.C.; Latallo, Z.S.; Chmielewska, J.: An assessment of an amidolytic assay for factor VII in the laboratory control of oral anticoagulants. Br. J. Haemat. 49: 49-75 (1981).

Radcliffe, R.; Bagdasarian, A.; Colman, R.; Nemerson, Y.: Activation of bovine factor VII by Hageman factor fragments. Blood 50: 611-617 (1977).

Radcliffe, R.; Nemerson, Y.: Activation and control of factor VII by activated factor X and thrombin. J. biol. Chem. 250: 388-395 (1975).

Radcliffe, R.; Nemerson, Y.: Mechanism of activation of bovine factor VII. Products of cleavage by factor $X_{\mathrm{a}}$. J. biol. Chem. 251: 4797-4802 (1976).

Seligsohn, U.; Kasper, C.K.; Østerud, B.; Rappaport, S.I.: Activated factor VII: presence in factor IX concentrates and persistence in the circulation after infusion. Blood 53: 828-837 (1979a).
Seligsohn, U.; Østerud, B.; Brown, S.F.; Griffin, J.H.; Rapaport, S.I.: Activation of human factor VII in plasma and in purified systems. Roles of activated factor IX, kallikrein, and activated factor XII. J. clin. Invest. 64: 1056-1065 (1979b).

Seligsohn, U.; Østerud, B.; Griffin, J.H.; Rapaport, S.I.: Evidence for the participation of both activated factor XII and activated factor IX in coldpromoted activation of factor VII. Thromb. Res. 13: 1049-1056 (1978a).

Seligsohn, U.; Østerud, B.; Rapaport, S.I.: Coupled amidolytic assay for factor VII: its use with a clotting assay to determine the activity state of factor VII. Blood 52: 978-988 (1978b).

Zaugg, H.: Thromboplastic activity of human arterial walls and its interaction with the plasmatic coagulation system. J. clin. Chem. clin. Biochem. 18: 545-549 (1980).

Zur, M.; Nemerson, Y.: The esterase activity of coagulation factor VII. Evidence for intrinsic activity of the zymogen. J. biol. Chem. 255: 5703-5707 (1980).

M.C.E. van Dam-Mieras, Department of Biochemistry, Limburg University, Beeldsnijdersdreef 101, NL-6200 MD Maastricht (The Netherlands) 